\author{
${ }^{1}$ Tri Wulandari Kesetyaningsih", ${ }^{2}$ Yoni \\ Astuti, ${ }^{3}$ Zulkhah Noor \\ ${ }^{123}$ Program Studi Pendidikan Dokter, \\ Universitas Muhammadiyah Yogyakarta \\ Jalan Brawijaya, Tamantirto, Kasihan, \\ Bantul, Yogyakarta 55183 \\ Email: tri_wulandari@umy.ac.id
}

\section{Aktivitas Fisik Rutin untuk Mencegah Penyakit Degeneratif}

\author{
The Routine Physical Activities to Prevent Degenerative Dis-
} eases

https://doi.org/10.18196/bdr.8176

\begin{abstract}
Degenerative or metabolic disease is a disease caused by excessive activities that give people no time to maintain their body health. This continuous condition can increase the death risk. This phenomenon is widely found with the existence of obesity in many places including in Gamping hamlet, Ambarketawang village, Gamping district, Sleman regency. Recently, the trend of this disease has gone up. Therefore, creating the society's awareness about this issue is necessary to do through an empowerment program. This program is expected to decrease the death risk caused by metabolic or degenerative disease mainly for housewives who have never-ending activities. The society empowerment program is implemented through an organization for women namely Family Welfare Program. This program implementation is done in some stages namely:1) early physical quality examination (body mass index, blood pressure, cholesterol levels, blood sugar and uric acid); 2) a group creation that concerns about healthy life; 3) socialization on healthy life pattern; 4) psychomotor routine gymnastics twice a week for 10 weeks; and 5) final physical quality examination. It is recorded from this empowerment program that $38.29 \%$ suffers from obesity, $6.38 \%$ suffers from diabetes mellitus (DM), $36.17 \%$ suffers from high uric acid and $10.64 \%$ suffers from hypercholesterolemia. After regular gymnastics twice a week in 10 weeks, it is recorded that the obesity decreases to $34.04 \%$ and the DM decreases to $4.26 \%$, while hypercholesterolemia increases to $17.02 \%$. The uric acid, on the other hand, remains stable. To maintain their further health, continuous routine gymnastics, periodic medical check-up (at least once a year), especially for people aged $>40$ years. Another success of this program is the creation of Healthy Life Caring Community.

Keywords: metabolic disease, obesity, gymnastics, healthy life
\end{abstract}

\title{
PENDAHULUAN
}

Pada zaman modern seperti sekarang ini, semakin banyak orang menderita sindroma metabolik. Sindroma metabolik adalah sekumpulan gejala yang terjadi secara bersamaan, gejala yang muncul diakibatkan karena adanya gangguan metabolism tubuh. Adapun gejala tersebut antara lain adalah tingginya tekanan darah, kadar gula darah, kadar kolesterol, dan kelebihan lemak di sekitar pinggang. Penderita sindroma metabolik berisiko menderita diabetes mellitus, stroke, dan penyakit jantung. Sindroma metabolik disebabkan oleh banyak hal, terutama karena pola hidup yang kurang sehat (Cozma et al., 2018; Michishita et al., 2016). Pola hidup kurang sehat yang dimaksud meliputi perilaku 
makan/minum, kurang gerak, cara menyikapi masalah hidup yang salah dan termasuk lingkungan hidup sekitar yang kurang sehat pula (Cozma et al., 2018).

Penyakit metabolik terkait dengan proses degeneratif (Cozma et al, 2018). Proses degeneratif sebenarnya secara alamiah terjadi pada manusia usia lanjut yang diakibatkan oleh menurunnya fungsi-fungsi fisiologis tubuh. Umumnya, fungsi fisiologis tubuh akan menurun setelah berumur 40 tahun ke atas. Besarnya penurunan fungsi fisiologis tubuh dipengaruhi oleh kualitas fisik seseorang ketika berusia kurang dari 40 tahun (McPhee et al., 2016). Kualitas fisik seseorang dipengaruhi oleh banyak hal, termasuk di_antaranya adalah secara internal kebiasaan beraktifitas fisik dan cara berpikir (kondisi psikis) dan secara eksternal adalah lingkungan, terutama lingkungan rumah, dan tempat bekerja.

Seorang ibu, baik ibu rumah tangga maupun ibu yang bekerja di luar rumah, memiliki fungsi domestik. Ia memiliki tanggung jawab terhadap kesejahteraan anggota keluarganya termasuk menjaga kondisi fisik rumah. Tugas ini sering menyebabkan seorang ibu tidak memiliki kesempatan yang cukup untuk melakukan aktivitas fisik yang terukur dan terarah. Dalam tugasnya, kegiatan ibu dalam rumah tangga banyak berkaitan dengan makanan dan minuman. Kurangnya aktivitas fisik dan pekerjaan sebagai penyedia makanan dan minuman menyebabkan ibu rumah tangga berisiko mengalami kegemukan. Jika ditambah dengan kondisi mental stres, kondisi tersebut akan meningkatkan risiko penyakit degeneratif pada ibu-ibu. Stress adalah kondisi kejiwaan yang dapat menimpa semua orang termasuk ibu-ibu. Selain itu, peran ibu sangat strategis dalam membentuk pola pikir dan perilaku sehari-hari dalam keluarganya- sehingga pola pikir dan perilaku seorang ibu juga dapat berimbas pada kesehatan anggota keluarganya.

Sejak tahun 1992, pemerintah Indonesia telah mengubah pola berpikir terhadap kesehatan, dari pola pikir berorientasi pada sakit ke pola pikir berorientasi pada sehat. Pola pikir yang berorientasi pada sakit, selalu berpikir dan berperilaku bagaimana mengobati orang sakit (kuratif), sedangkan pola pikir yang berorientasi pada sehat, selalu berpikir bagaimana hidup secara sehat dan terhindar dari penyakit (pencegahan/ preventif). Sampai sekarang banyak orang melakukan dan mempromosikan agar selalu mengedepankan pencegahan daripada mengobati penyakit.

Menurut Kemenkes (2017), sekitar 25,8 \% penduduk Indonesia usia dewasa tergolong obesitas, dua kali lipat dibandingkan tahun sebelumnya yaitu hanya 10,6 \%. Jadi 1 di antara 4 orang Indonesia menderita obesitas. Di DIY, menurut Riskesdas (2010) cit. Kurdanti et al. (2015) 21,7\% penduduk dewasanya termasuk overweight dan obesitas. Belum ada data angka obesitas di tingkat kecamatan, apalagi kelurahan.

Kecamatan Gamping termasuk wilayah aglomerasi perkotaan Yogyakarta, yang 
berkembang pesat menjadi pusat pendidikan, terutama pendidikan tinggi. Terdapat beberapa perguruan tinggi berlokasi di Kecamatan Gamping, terutama Kelurahan Ambarketawang. Kondisi ini berdampak pada gaya hidup masyarakat di sekitar kampus. Mereka disibukkan dengan melakukan bisnis terkait dengan pelayanan mahasiswa penghuni kost. Usaha tersebut antara lain adalah laundry, warung makan atau usaha dagang atau jasa yang lain. Kesibukan baru ini berakibat pada semakin sedikitnya waktu untuk istirahat dan berolah raga, dan meningkatkan stress. Pola hidup yang tidak baik, kurang berolah raga dan tingkat stres yang tinggi dapat meningkatkan risiko terkena sindroma metabolik. Beberapa ibu-ibu mengeluhkan bahwa mereka kurang sehat, gemuk, dan khawatir terkena penyakit diabetes, gagal ginjal, gagal jantung, atau stroke. Akhirakhir ini juga dirasakan semakin banyak yang meninggal karena penyakit tersebut.

Berkaitan dengan hal tersebut di atas, penting dilakukan upaya untuk mencegah penyakit bahkan kematian akibat komplikasi dari sindroma metabolik. Pembentukan kader dan praktek aktivitas fisik bersama diharapkan dapat mencegah munculnya sindroma metabolik pada ibu-ibu khususnya dan meluas kepada anggota keluarga masingmasing.

\section{METODE PELAKSANAAN}

Kegiatan Pengabdian Kepada Masyarakat (PKM) diawali dengan sosialisasi kegiatan yang dilaksanakan pada saat pertemuan rutin PKK RT. Pertemuan tersebut dihadiri oleh semua anggota PKK RT 03 RW 17, Dusun Gamping Kidul, Kelurahan Amabrketawang, Gamping, Sleman. Pada pertemuan tersebut ibu-ibu PKK menyambut baik dan kemudian disepakati untuk jadwal pemeriksaan kesehatan awal.

Pada pertemuan berikutnya dilakukan pemeriksaan kesehatan periode awal, yaitu mengukur berat badan (BB), tinggi badan (TB) untuk menentukan indeks masa tubuh (IMT); yang kemudian digunakan untuk menentukan penggolongan tingkat kegemukan, yaitu normal, gemuk, atau obesitas. Selain itudilakukan pengukuran tekanan darah dan pemeriksaan darah untuk mengukur kadar kolesterol, kadar gula dan kadar asam urat sebagai kegiatan screening tingkat kebugaran ibu-ibu setempat. Dari hasil pemeriksaan, kemudian dilakukan penggolongan status obesitas ibu-ibu PKK RT 03, dan status kesehatan terkait penyakit metabolik.

Adapun alat-alat yang digunakan adalah timbangan digital untuk mengukur berat badan, statur meter $2 \mathrm{~m}$ untuk mengukur tinggi badan, tensi meter jarum untuk mengukur tekanan darah, dan set untuk mengukur parameter darah yaitu kadar gula darah, 
kolesterol, dan asam urat yang terdiri atas blood lancet single use, kapas alkohol 70\%, dan alat pengukur parameter darah GCU merk Easy Touch.

Penggolongan status kesehatan Indeks Massa Tubuh (IMT) digunakan untuk menentukan penggolongan obesitas, overweight atau normal serta kurang BB. IMT e” 27 digolongkan sebagai penderita obesitas, IMT 25-27 tergolong overweight, IMT 19-24,9 tergolong normal dan IMT $<19$ tergolong kurang. Pemeriksaan tekanan darah tergolong hipertensi apabila tekanan sistolik > $140 \mathrm{mmHg}$ dan diastolik e” 90 mmHg. Pemeriksaan Gula Darah Sewaktu (GDS) dengan nilai $>200$ mg/dl mengindikasikan sebagai penderita DM dan $<200$ mg/dl. Kadar Kolesterol < 200 termasuk normal, 200-239 termasuk batas tinggi, e” 240 termasuk hiperkolesterolemia. Penentuan penggolongan asam urat, tergantung pada usia ibu-ibu. Untuk ibu-ibu berusia $>40$ tahun, angka normalnya adalah 2-8 mg/dl, sedangkan yang berusia 18-39 tahun, angka normalnya adalah 2-6,5 mg/dl.

Kegiatan dilanjutkan dengan penyuluhan mengenai pola hidup sehat bagi ibu-ibu PKK dengan materi: (1) Mengapa ibu obesitas berisiko menderita penyakit degeneratif?; (2) Apa saja tanda sindroma metabolik?; dan (3) Ajakan menerapkan hidup sehat untuk mengurangi risiko penyakit akibat sindroma metabolik, dengan penjelasan tentang menu sehat, pentingnya aktivitas fisik rutin/ olah raga bagi kesehatan, dan manajemen stres.

Implementasi program penerapan pola hidup sehat berupa "aktivitas fisik 30 menit setiap hari" disepakati berupa senam yang dilakukan $2 \mathrm{x}$ seminggu, masing-masing dilakukan selama satu jam. Pada akhir program, dilakukan pemeriksaan kesehatan untuk mengukur kualitas fisik kedua (post perlakuan) berupa pemeriksaan BB, TB, TD, kadar kolesterol, kadar gula darah (GDS) dan kadar asam urat. Sebagai penghargaan dan motivasi, akan diberikan hadiah pada ibu-ibu yang berhasil memperbaiki kualitas fisik berdasarkan parameter yang diukur yaitu BB, TB, TD, kadar kolesterol dan kadar gula (GDS).

Data yang terkumpul dari pemeriksaan berupa BB, TB, TD, kadar gula darah, kadar kolesterol, kadar asam urat, digunakan untuk menentukan status obesitas berdasarkan IMT, dan kondisi status gambaran parameter darah. Dari data sebelum dan sesudah kemudian dianalisis secara deskriptif untuk melihat kecenderungan perubahan parameter kesehatan fisik setelah aktivitas fisik berupa senam $2 \mathrm{x}$ seminggu.

\section{HASIL DAN PEMBAHASAN}

Dusun Gamping Kidul terletak di sebelah selatan Jalan Wates KM 5,5. Dusun Gamping Kidul menempati area yang strategis yaitu berada pada jalur utama Yogyakarta- 


\section{2}

Jurnal BERDIKARI

Vol.8 №.1 Februari 2020

Purwokerto/Jakarta. Hal ini menyebabkan wilayah ini berkembang dengan pesat dalam bidang ekonomi, perdagangan ${ }_{2}$ dan kependudukan. Dusun ini juga menjadi wilayah perluasan perkotaan Yogyakarta ke arah Barat, sebagai pusat pariwisata dan pendidikan. Di Dusun ini terdapat TK, SD, SMP, SMA dan dua kampus perguruan tinggi yaitu Universitas Jenderal Ahmad Yani dan Universitas BSI.

Secara administratif, Dusun Gamping Kidul berbatasan dengan Dusun Gamping Tengah di sebelah utara dan barat, berbatasan dengan Kelurahan Tamantirto, Kecamatan Kasihan, Kabupaten Bantul di sebelah selatan dan berbatasan dengan Sungai Bedog di sebelah timur. Dusun Gamping Kidul terdiri atas 4 RW (RW 16,17,18 dan 19) dan 13 RT dengan jumlah penduduk 2.968 (tahun 2016). Kegiatan PKM dilakukan di salah satu RT yaitu RT 03/ RW 17, yang memiliki penduduk berjumlah 80 KK. Dalam organisasi PKK, terdapat tiga Dasa Wisma yaitu Dasa Wisma Matahari, Teratai, dan Aster. Setiap bulan setiap Dasawisma mengadakan pertemuan satu kali dan pertemuan PKK di tingkat RT satu kali. Pertemuan rutin ini digunakan untuk menjalin silaturahim diantara ibu-ibu anggota PKK dan sosialisasi program pemerintah kepada masyarakat.

Kegiatan PKM diawali dengan sosialisasi kegiatan (Gambar 1), dilanjutkan dengan pemeriksaan kesehatan periode awal, yaitu mengukur berat badan (BB) dan tinggi badan (TB) untuk menentukan indeks masa tubuh (IMT) (Gambar 2) yang kemudian digunakan untuk menentukan penggolongan tingkat kegemukan, yaitu normal, gemuk atau obesitas. Pengukuran tekanan darah dan pemeriksaan darah untuk mengukur kadar kolesterol, kadar gula, dan kadar asam urat. Dari hasil pemeriksaan, dapat dilakukan penggolongan status obesitas ibu-ibu PKK RT 03, dan status kesehatan terkait penyakit metabolik dan keatifan dalam kegiatan senam rutin. Hasil penggolongan disampaikan pada Tabel 1.

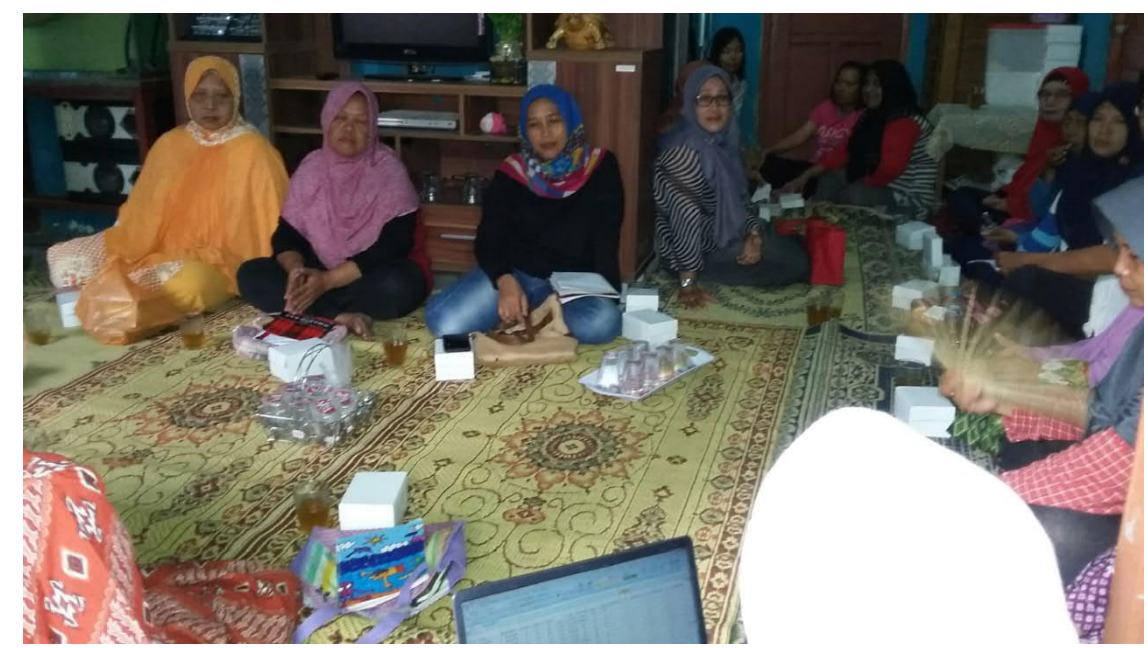

Gambar 1. Sosialisasi Program PKM pada ibu-ibu PKK 

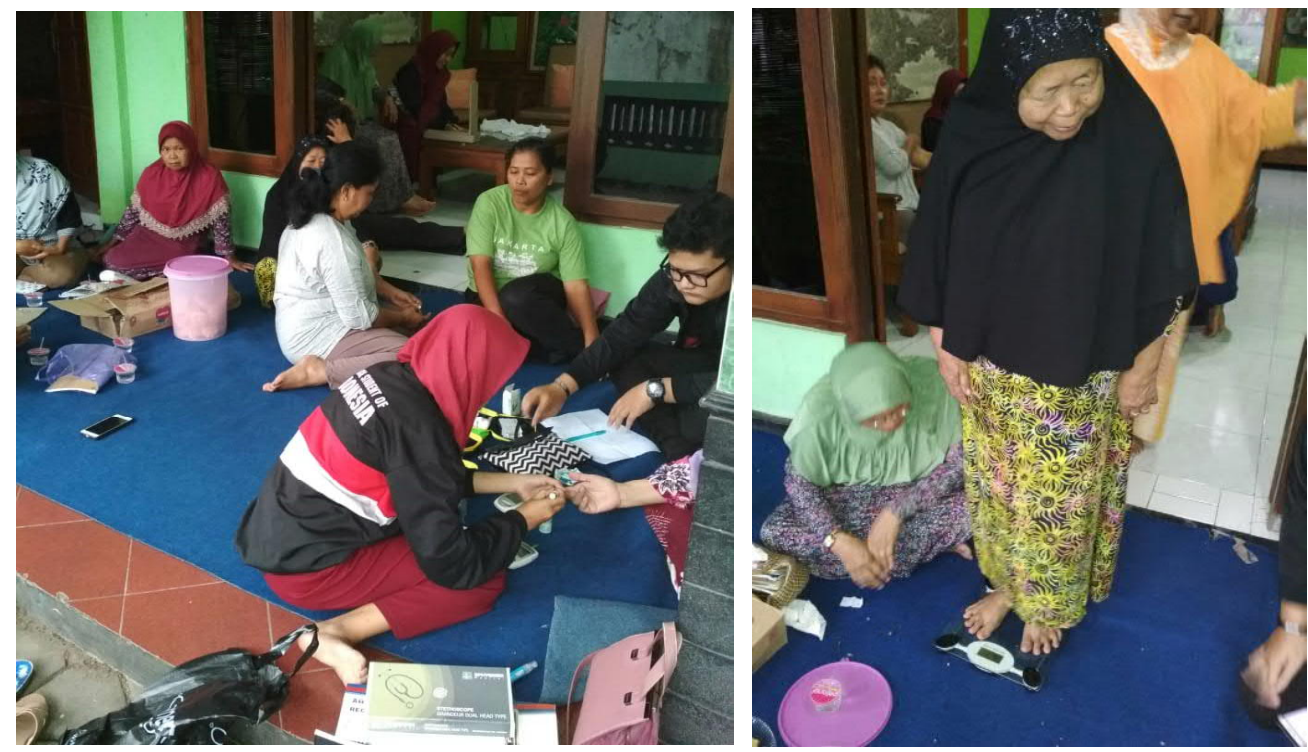

Gambar 2. Pemeriksaan Status Kesehatan Tahap 1

\section{Kondisi Kesehatan Awal}

Tabel 1 berikut menunjukkan bahwa terdapat 47 orang ibu-ibu anggota PKK RT yang bersedia diperiksa kondisi kesehatannya. Dari 47 orang tersebut, ternyata 36,17\% di antaranya termasuk kategori obesitas, yaitu yang memiliki IMT > 27. Angka ini melebihi angka obesitas nasional yaitu sebesar 21,8\% tahun 2018 (Kemenkes RI, 2018). Penderita DM hanya sebesar 6,38\%, lebih rendah dari angka nasional yaitu sebesar 10,9\% pada tahun 2018 (Riskesdas, 2018). Penderita hipertensi sebesar 36,17\%, sedikit lebih tinggi daripada angka hipertensi nasional yang hanya 34,1\% tahun 2018 (Kemenkes RI, 2018). Menurut Kemenkes RI 2018, hipertensi hasil pengukuran di masyarakat menunjukkan angka yang lebih tinggi dibandingkan hasil diagnosis dokter yang hanya menunjukkan angka 8,8\% tahun 2018. Tidak ada data penderita hiperkolesterolemia di Indonesia atau DIY, tetapi prevalensi penyakit jantung di DIY berkisar 2\%. Penyakit jantung merupakan salah satu bentuk komplikasi dari hiperkolesterolemia. Penderita hiperkolesterolemia pada ibu-ibu PKK menunjukkan angka 10,64\%. Hal ini perlu diwaspadai agar tidak berlanjut menjadi penyakit jantung atau bentuk komplikasi yang lain seperti stroke.

\section{Aktivitas Fisik Rutin}

Setelah pemeriksaan awal, pada hari minggu berikutnya mulai dilakukan latihan fisik berupa senam selama satu jam. Pelaksanaan senam sebagai aktivitas fisik disepakati untuk dilakukan 2 x seminggu yang dilaksanakan setiap hari selasa sore jam 16.00-17.00 dan 
hari minggu jam 06.00-07.00. Pelaksanaan senam telah berlangsung secara rutin selama hampir 2 bulan dan diikuti oleh sekitar 30-40 orang ibu-ibu PKK RT03, bahkan diikuti oleh ibu-ibu dari luar RT 03. (Gambar 3 dan 4). Dari 3 Dasawisma yang ada di RT 03, Dasawisma yang paling banyak aktif mengikuti senam adalah Dasawisma Matahari (75\%). Rerata persentase ibu-ibu yang mengikuti senam secara keseluruhan sudah cukup banyak (57\%). Namun demikian, masih diperlukan upaya pendekatan agar partisipasi ibu-ibu dalam kegiatan senam semakin meningkat.

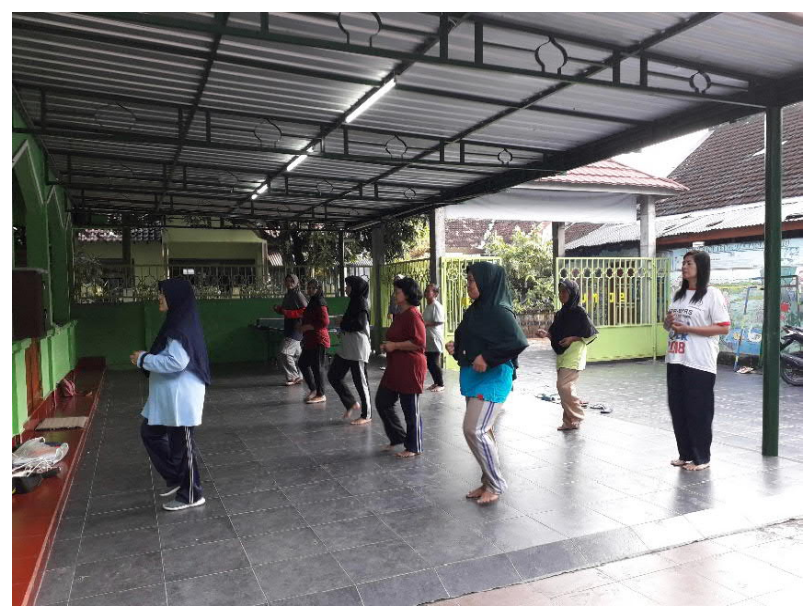

Gambar 3. Senam Rutin 2 x Seminggu pada Awal Program

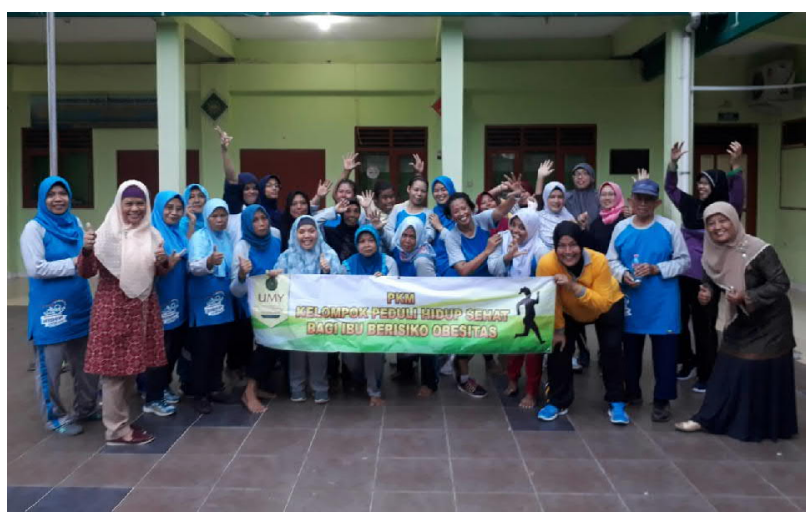

Gambar 4. Peserta Senam Mendapatkan Bantuan Seragam

Tabel 1. Kondisi Kesehatan Ibu-ibu PKK RT 03/RW 17 Dusun Gamping Kidul pada Awal Kegiatan

\begin{tabular}{lcccccccc}
\hline $\begin{array}{c}\text { Dasa } \\
\text { Wisma }\end{array}$ & $\begin{array}{c}\text { Jml } \\
\text { orang }\end{array}$ & $\begin{array}{c}\text { Rerata } \\
\text { usia (th) }\end{array}$ & Obesitas & DM & $\begin{array}{c}\text { Hiper } \\
\text { kolesterol }\end{array}$ & AU tinggi & Hipertensi & Aktif senam \\
\hline Matahari & 12 & 48,75 & $\begin{array}{c}4 \\
(33,33 \%)\end{array}$ & $\begin{array}{c}0 \\
(0 \%)\end{array}$ & $\begin{array}{c}0 \\
(0 \%)\end{array}$ & $\begin{array}{c}4 \\
(33,33 \%)\end{array}$ & $\begin{array}{c}6 \\
(50 \%)\end{array}$ & $\begin{array}{c}9 \\
(75 \%)\end{array}$ \\
\hline Aster & 16 & 50,75 & $\begin{array}{c}7 \\
(43,75 \%)\end{array}$ & $\begin{array}{c}(6,25 \%) \\
\text { (1) }\end{array}$ & $\begin{array}{c}(12,5 \%) \\
2\end{array}$ & $\begin{array}{c}(0 \%) \\
(37,5 \%)\end{array}$ & \begin{tabular}{c}
$(50 \%)$ \\
\hline
\end{tabular} \\
\hline Teratai & 19 & 46,58 & 6 & 2 & 3 & 0 & 5 & 10 \\
& & & $(31,58 \%)$ & $(10,5 \%)$ & $(15,79 \%)$ & $(0 \%)$ & $(26,32 \%)$ & $(52,63 \%)$ \\
\hline Total & 47 & & 17 & 3 & 5 & 4 & 17 & 27 \\
& & & $(36,17 \%)$ & $(6,38 \%)$ & $(10,64 \%)$ & $(8,51 \%)$ & $(36,17 \%)$ & $(57,45 \%)$ \\
\hline
\end{tabular}


Kegiatan senam untuk sementara diistirahatkan selama bulan Ramadan dan dilanjutkan lagi setelah bulan Ramadan. Pada awalnya, senam dipimpin oleh ketua pengabdi, tetapi untuk selanjutnya dipimpin oleh instruktur yang kebetulan merupakan anggota PKK RT 03. Selain itu ${ }_{2}$ juga telah terbentuk kepengurusan kelompok peduli sehat "Fit and Fresh"-Selama kegiatan senam juga ada inisiatif dari warga untuk mengumpulkan iuran sukarela setiap kali senam. Uang tersebut digunakan untuk keperluan operasional kegiatan senam, memberikan penghargaan jasa kepada instruktur dan membeli beberapa peralatan yang diperlukan. Pengabdi juga memberikan bantuan seragam gratis kepada 40 orang ibu-ibu yang aktif megikuti senam dan timbangan berat badan. Direncanakan juga untuk yang akan datang, pelatihan untuk ibu-ibu pengurus grup senam sehat tersebut agar dapat melakukan pemeriksaan darah secara mandiri di bawah pengawasan seorang perawat. Hal ini dimaksudkan agar keberlanjutan kegiatan ini terjaga.

Penyuluhan mengenai pentingnya menjaga kesehatan dengan menerapkan pola hidup sehat dilakukan secara paralel dengan kegiatan senam. Adapun materi yang telah diberikan adalah (1) penyakit metabolik dan faktor risikonya; (2) kadar gula darah, DM dan menjaga agar tidak terkena DM; (3) kadar kolesterol darah, hiperkolesterolemia dan cara pencegahannya; (4) menyajikan menu sehat bagi keluarga; (5) pentingnya aktivitas fisik yang terukur dan sesuai dengan kebutuhan.

Kegiatan penyampaian materi dan senam dilanjutkan setelah bulan Ramadan selesai. Pemeriksaan tahap dua terhadap gambaran darah dan berat badan untuk menilai perubahan kondisi kesehatan sebagai dampak kegiatan senam dilakukan sebelum memasuki bulan Ramadan, yaitu setelah 10 minggu kegiatan senam rutin 2x seminggu.

\section{PENGARUH KEGIATAN}

Hasil pemeriksaan tahap dua ditampilkan pada Tabel 2. Pada Tabel 2 tampak bahwa terdapat penurunan persentase penderita obesitas 36,17\% menjadi 34,04. Persentase ibu-ibu yang tergolong DM juga menurun dari 6,38\% menjadi 4,26\%. Namun persentase ibu-ibu yang tergolong hiperkolesterolemia justru meningkat dari 10,64\% menjadi $17,02 \%$. Sedangkan pada kadar asam urat, tidak terjadi perubahan persentase ibu-ibu dengan kadar asam urat tinggi secara keseluruhan antara sebelum senam dan sesudah senam selama 10 minggu. 
Tabel 2. Kondisi kesehatan Ibu-ibu PKK RT03/RW17 Dusun Gamping Kidul pada Akhir Kegiatan

\begin{tabular}{cccccccc}
\hline $\begin{array}{c}\text { Dasa } \\
\text { Wisma }\end{array}$ & Jml (orang) & $\begin{array}{c}\text { Rerata usia } \\
\text { (th) }\end{array}$ & Obesitas & DM & $\begin{array}{c}\text { Hiper } \\
\text { kolesterol }\end{array}$ & AU tinggi & Hipertensi \\
\hline Matahari & 12 & 48,75 & $\begin{array}{c}3 \\
(25,0 \%)\end{array}$ & $\begin{array}{c}0 \\
(0 \%)\end{array}$ & $\begin{array}{c}1 \\
(8,33 \%)\end{array}$ & $\begin{array}{c}2 \\
(16,67 \%)\end{array}$ & - \\
\hline Aster & 16 & 50,75 & $\begin{array}{c}7 \\
(43,75 \%)\end{array}$ & $\begin{array}{c}(0 \%) \\
(18,75 \%)\end{array}$ & $\begin{array}{c}(0 \%) \\
0\end{array}$ & - \\
\hline Teratai & 19 & 46,58 & 6 & 2 & 4 & 2 & - \\
& & & $(31,58 \%)$ & $(10,5 \%)$ & $(21,05 \%)$ & $(10,53 \%)$ & \\
\hline Total & 47 & & 16 & 2 & 5 & 4 & - \\
& & & $(34,04 \%)$ & $(4,26 \%)$ & $(17,02 \%)$ & $(8,51 \%)$ & \\
\hline
\end{tabular}

Penelitian yang dilakukan oleh Hengkengbala et al (2013), aktivitas fisik dapat meningkatkan kadar HDL, tetapi belum diketahui intensitas senam yang dapat mempengaruhi peningkatan HDL secara signifikan. Dalam pengabdian ini, peningkatan kolesterol total setelah senam masih harus diteliti lebih lanjut apakah terjadi karena HDL yang meningkat atau bukan. Menurut Zuhroiyyah et al. (2017), aktivitas fisik harian (habit) berpengaruh pada kadar kolesterol total dan LDL di masyarakat Jatinangor, Jawa Barat. Hal ini mengindikasikan bahwa diperlukan aktivitas fisik jangka lama (kebiasaan hidup) untuk dapat mempengaruhi kadar kolesterol total.

Pada parameter asam urat, hasil pemeriksaan setelah senam rutin selama 10 minggu secara keseluruhan memang tidak mengalami perubahan. Namun, apabila dilihat pada tingkat Dasawisma, tampak bahwa penurunan persentase penderita asam urat tinggi terjadi pada dasawisma yang memiliki tingkat partisipasi senam tinggi (Dasawisma Matahari 75\%). Menurut Dayana dan Baharudin (2015), semakin tinggi aktivitas fisik penderita penyakit metabolik, semakin rendah kadar asam uratnya. Meskipun tidak disebutkan intensitas fisik yang diperlukan untuk menurunkan kadar asam urat, pengabdian ini terdapat indikasi bahwa senam rutin $2 \mathrm{x}$ seminggu selama 10 minggu kemungkinan dapat mengurangi kadar asam urat pada ibu-ibu PKK RT 03.

Pada parameter glukosa darah, menurut beberapa peneliti (Nurayati dan Adriani, 2017; Nur et al, 2016; Putri, 2016) aktivitas fisik berkorelasi negatif dengan kadar gula darah sehingga dapat mencegah DM pada orang non DM dan mengontrol kadar gula darah pada penderita DM. Pada pengabdian ini menunjukkan penurunan persentase ibu-ibu yang tergolong DM setelah aktivitas senam rutin selama 10 minggu. Hasil ini menandakan bahwa aktivitas fisik kemungkinan dapat menurunkan kadar gula darah.

Secara keseluruhan, kegiatan senam rutin telah menunjukkan dampak positif terhadap indikator kesehatan ibu-ibu PKK di lingkungan RT03 RW17. Dengan demikian, diharapkan kegiatan ini dapat berlanjut bahkan dikembangkan untuk menjadi contoh penerapan pola hidup sehat bagi kalangan ibu-ibu di wilayah lainnya. Masih perlu 
ditekankan secara terus menerus agar masyarakat memahami pentingnya menerapkan pola hidup sehat dalam kehidupan sehari-hari dan tidak hanya meningkatkan aktifitas fisik saja tetapi juga mengatur pola makan, pola istirahat, dan manajemen stres. Pada akhir program, pengabdi memberikan hadiah kepada 2 orang anggota ibu-ibu PKK yang berhasil memperbaiki kondisi kesehatannya dengan parameter IMT dan gambaran darah sebagai penghargaan.

\section{SIMPULAN}

Penerapan aktivitas fisik rutin dan penyuluhan tentang pentingnya penerapan pola hidup sehat untuk mencegah penyakit metabolik menunjukkan dampak positif bagi ibuibu PKK Gamping Kidul RT 03/ RW 17 Ambarketawang, Gamping, Sleman yaitu terjadi penurunan persentase penderita obesitas dan DM dari 36,17\% menjadi 34,04\% untuk obesitas dan 6,38\% menjadi 4,26\% untuk DM. Namun, persentase ibu-ibu yang tergolong hiperkolesterolemia justru meningkat dari 10,64\% menjadi 17,02\%. Akan tetapi, pada kadar asam urat, tidak terjadi perubahan persentase ibu-ibu dengan kadar asam urat tinggi secara keseluruhan.

\section{UCAPAN TERIMA KASIH}

Ucapan terimakasih disampaikan kepada LP3M UMY yang telah memberikan dana hibah tahun 2018-2019 untuk pelaksanaan pengabdian kepada masyarakat ini.

\section{DAFTAR PUSTAKA}

Cozma A., Adela ST, Laura U., Adriana F., Ramona S., Crina M., et al., 2018 "Unhealthy lifestyle and the risk of metabolic syndrome- the Romanian experience," J Mind Med Sci. 2018; 5(2): 218229. doi: $10.22543 / 7674.52 . P 218229$

Dayana B., dan Bahrudin U. Hubungan antara Intensitas Aktivitas Fisik dan Kadar Asam Urat Serum pada Populasi Sindrom Metabolik. Media Medika Muda: 4 (4), Oktober 2015. Pp 509-521 Hengkebala G., Polii H., dan Wungouw, HIS. Pengaruh Latihan Fisik Aerobik terhadap Kolesterol High Density Lipoprotein (HDL) Pria dengan Berat Badan Lebih (Overweight). Jurnal e-Biomedik (eBM):2013(1):1.pp 284-290

Kemenkes RI. Hasil Utama Riskesdas 2018. Available 20 Juni 2019 at http://www.depkes.go.id/ resources/download/info-terkini/hasil-riskesdas2018.pdf
Kurdanti W., Suryani I., Syamsiatun,NH., Siwi, LP., Adityanti1, MM., Mustikaningsih D., et al., Faktor-Faktor yang Mempengaruhi Kejadian Obesitas pada Remaja. Jurnal Gizi Klinik Indonesia. 2015:11(4): 179-190

McPhee JS., French, DP., Jackson, D., Nazroo J., .Pendleton, N. Hans Degens Physical activity in older age: perspectives for healthy ageing and frailty. Biogerontology. 2016;17:567-580

Michishita R, Matsuda T., Kawakami S., Kiyonaga A., Tanaka H., Morito, N., and Yasuki Higaki. The Association Between Unhealthy Lifestyle Behaviors and the Prevalence of Chronic Kidney Disease (CKD) in Middle-Aged and Older Men. J Epidemiol 2016;26(7):378-385

Nurayati L. dan Adriani M. Hubungan Aktifitas Fisik dengan Kadar Gula Darah Puasa Penderita Diabetes Melitus Tipe 2. Amerta Nutr. 2017 80- 
Jurnal BERDIKARI

Vol.8 No.1 Februari 2020

8780 DOI : 10.2473/amnt.v1i2.2017.80-87

Nur A, Veny Wilya, V., dan Ramadhan, R. Kebiasaan Aktivitas Fisik Pasien Diabetes Mellitus terhadap Kadar Gula Darah di Rumah Sakit Umum Dr. Fauziah Bireuen. SEL Vol. 3 No. 2 November 2016: $41-48$

Putri, EL. Hubungan Antara Latihan Jasmani dengan Kadar Glukosa Darah Penderita Diabetes. Jurnal Berkala Epidemiologi, Vol. 4 No. 2, Mei 2016: 188-199

Zuhroiyyah SF., Sukandar H., dan Sastradimaja SB,. Hubungan Aktivitas Fisik dengan Kadar Kolesterol Total, Kolesterol Low- Density Lipoprotein, dan Kolesterol High-Density Lipoprotein pada Masyarakat Jatinangor. JSK. 2017 (2):3. Pp 116122 